\title{
TOXIGENIC FUNGI: ECOLOGY AND PREVENTION OF THEIR MYCOTOXIN PRODUCTION (A REVIEW)
}

\author{
(Hongos toxicogénicos: Ecología y prevención de la producción de \\ sus micotoxinas (Revisión)) \\ Cecilia L. Fulgueira \& Alfredo L. Borghi \\ Cenuro de Referencia de Micologia (CEREMIC). \\ Faculad de Ciencias Bioquímicas y Fannacéuticas. \\ Universidad Nacional de Rosario. Suipacha 531. 2000 Rosario, Agentina. \\ FAX:+54-341-4804597, E-mail: cfulguei@Bbioyf.urredu ar
}

\begin{abstract}
Palabras Clave: Aspergillus, Fusarium, Penicilinm, Alternaria, micoloxinas, hongos toxicogénicos, ecologia, prevención
\end{abstract}

Key words: Aspergillus, Fusarium, Penicillium, Alternaria, mycotoxins, lo.jgenic fungi, ecology, prevention.

\section{RESUMEN}

Las acinidades inmanas, entre ellas la agricultura, interfieren con la dinamica de las poblaciones fungicas, pudiendo afeclar en mayor o menormedida los tamaños y la estructura de la comumidad. Si bien muchas especies de Hyphomycetes son beneficiosas y aún esenciales para el desarrollo de ciertos cultivos, otras son firoparogenas y/o roxicogénicas, pudiendo estas illlimas producir micoloxinas, que por su accion ijenen relevancia en salud pública.

Desde um punto de vista agricola, se ha establecido que las especies toxicogénicas màs significativas pertenecen principalmente a los géneros Aspergillus, Fusarium, Penicillium y Alhernaria

En la presente revisión, se discuten los principales determinantes ecológicos asi conlo la capacidad para producir micoloximas de cierias especies integrantes de estos taxa, contribuyendo de esta manera a la comprensión del aspecto ecotoxicologico del problema.

Las micoloxinas son contaminantes naturales de los alimentos y materias primas alimentarias, por lo tanlo, las estrategias ideales para su comrol tienden a prevenir el crecimiento fingico y la produccion de sus metabolitos secundarios tóxicos. Para ello se ha disenado una serie de nedidas temporales con el propósiro de reducir esta comiaminación. Entre ellas pueden desiacarse el desarrollo de programas de manejo incegrado de culinos y el control de condiciones durante la cosecha y almacenamiento del producto final. Las soluciones definitivas al problema de comaminación con micotoxinas, requieren un tiempo más prolongado para su desarrollo e implementación. Dichas estrategias, inchyen el uradicional desarrollo de resistencia a la inva- sión fingica en la planta hospedera. Otros mélodos allemativos, imchyen el control quimico o biolbgico del crecimiento fúngico y la mamipulación genética de especies toxicogéricas, con el propósito de interrumpir su metabolismo de formación.

En la presente revisión, se discuten los procedimientos provisorios y a largo plazo sendientes a disminuir o evitar la contaminación de los alimentos con micotoxinas

\section{SUMMMARY}

Human activilies, such as agriculture, interfere with the dinamics of fungal populations by affecting in high of low degree the size and structure of the community. Even though, many fungal species are benefroial and essential for the development of certain crops, there are other groups having a phytopathogenic and for atoxigenic mature which makes them to produce mycoroxins that, because of their acsion, becone relevant in public health.

From the agriculiural point of view, it may be stated that the most significant torigenic fungi belong to the Aspergillus, Fusarium, Penicillium and Alternaria genera.

The main ecological characteristics as well as the ability of cerlain species belonging 10 these taxa to produce mycotoxims are discussed in this review so as 10 help in the understanding of the ecotoxicologic fealure of the problenis.

Mycotoxins are considered matural contaminants of foods and alimentary rav materials, therefore the ideal sirategies designed for heir conirol ain to prevent the fungal growth as well as the production of their 
secondary toxic metabolites. A series of temporary measures has been designed to this effect in order to minimize this contaminations, such as the development of programs to get an integrated handling of cultures and the control of conditions during the crop and storage of the final product. Definitive solutions to the problem of contamination by roxins, require a longer period of ime for their evolution and implementation. These strategies include the ustal resistance to the fungal invasion in the host plant. Another alternotive methods include chemical or biological control of the fungal growth and the genetic handling of toxigenic species with the purpose of interrupting their metabolism of production.

In this review, both the tenporary and long-tery procedures tending to minimize or else avoid the contamination of food by mycoloxins are also discussed.

\section{1) Fungi in nature}

Fungi are ubiquitous both in nature and domestic enviroments, and any kind of organie matter provides an adequate substrate for their growth (De Nijs el al. 1996).

Human activities affect dimensions as well as structures of fungal populations. Construction, wars, recreation, and agriculture disnupt great areas of soil and vegetation; disruption causes redistribution of fungal propagules and provides nutrients to fungi. Many fungi Lake advantage of these resources supplied by man. This results in the association of fungal populations with different human activities, especially agriculture. Nevertheless, human activity, determines in a partial way, quality and quantity of the fungi, while this infuences man's activities, domestic animals and ever man himself (Cotty el al. 1994).

One fungal characteristic is the ability lo produce secondary melabolites. In comparison with primary metabolites which are essential for the functioning of metabolic tracts and which are synhlesized during the aclive growing phase, secondary metabolites have no apparent biochemical role, and their biosynthesis occurs mainly in the stationary plase of growth (Smith \& Moss, 1985; Basílico, 1995).

Thus, through their metabolites, fungi may be beneficial for humanity, in many' ways, for instance, playing important roles in the production of cheese, antibiotics, vitamins, enzymes, and glycerol (Davies \& Diener, 1987; Ellis et al., 1991). However, mnny fungi are also hannful and may cause damage to foods or produce toxic substances such as secondary metabolites known as mycoloxins. They can be produced on a wide range of agricultural commodities and in a diverse range of situations. Due to their various toxic effects and their generally good thermal stability, the presence of mycotoxins in foods and feeds is potencially hazardous for the health of both humans and animals and causes very important economic losses (Smith \& Henderson, 1991; Shotwell, 1991; Pier, 1992; Laciaková et al, 1995; Pittel, 1998). This topichas a special relevance for rural populations in developing counuries, for whom the hazards posed by natural compounds can exceed the effects of manmade chemicals (Thiel, 1998).

None of the mycotoxins lias an acute toxicity approaching those of the macromolecular toxins of bacleria. However they may be quite widespread in foods, or in the raw materials used in their production, and some of them may pass through the food chain to commodivies which have not been conlaminated by moulds (Moss, 1998).

Among terrestrial fungi, filamentous fungi may produce mycoloxins, while yeasts do not produce them (Miller, 1995). The production of these toxic metabolites is not limited to one group of fungi. Although we may find toxigenic fungi within Zygomycetes and Ascomycetes classes, the principal genera of fungi known to be producers of mycotoxins may be found in the Hyphomycetes (Smirh \&Mass, 1985).

\section{II) Toxigenic fungi and their ecology}

\section{II.a) Toxigenic fungi in the frelds and in storage}

Allhougl all plants may suffer fungal infection, most of the researches have been carried oul with cereal grain, since human diet as well as that of domestic animals throughout the wotld is based on these grains (De Nijs et al., 1996).

Toxigenic fungi associated with crops have been, throughout history, included in two main categories: field fungi and storage fungi (Miller, 1995). However, both concepts are not always representative because of the presence of species which are able 10 grow in both habitat.

Fungal allack on grains of cereals may already occur when they are reaching maturity in the spikes. The damaging organisms are, among others, species of the genera Alternurin, Chadosporium and Fusarium. Because they occur in the fields they are called field fungi. They are adapted to clanging field conditions related with the gradual maturation of the grains. Humidity contents in the seeds higher than $25 \%$ are necessary for the activity of these fungi (Aganwal \& Sinclair, 1987; Moss, 1991). The activity of this mycota reduces the values of seeds and the ability of some species to produce toxic merabolites.

The organisms that produce deterioration and loss of quality in barns, farms, and silos are known as storage fungi. Fungi present in stored seeds have long been known, as saprophytic opportunistic invaders of naturally dried plant tissue or dead organic matter (Hudson, 1986; Chelkowsky 1991). The group comprises a number of xerotolerant species of the Aspergillus and Penicillium 
gevera, sone of which may be metabolically active in seeds with humidity contents as low as $13 \%$ (Wicklow, 1994). Where their activity is nol stopped, by keeping Jow temperature and storage humidity, they are capable of danaging the soeds in a very short time period (Agarval \& Sinclair, 1987). In developing countries it has been reported that these fungi destroy more than $30 \%$ of the stored grains. Besides quantitative losses, the quality of the stored grains may also be affected, espectally in terms of vigour, germinability and nutritious value. A certain number of the species involved produce mycotoxins. Conidia and sclerolia of the mosi aggressive of these storage fungi are frequently isolated from soil (Cotty, 1989; Kozakiewicz, 1989; Wicklow. 1994). Therefore, the original source of the fungi in bodh cases is the field (Miller, 1995). Prinarily the fungus-host plant relationship and other biological interactions (relations with other inicroorganisms, insects, elc.) govern fungal invasion before harvest. The growth of fungi after harvest is governed by crop factors (nutrients, genolype and seed resistance), physical factors (temperature, humidity) and biotic factors (interactions with other microorganisms, presence of insects and inoculum ralio). Seeds developed in a plant may therefore be exposed to an infection by field fungi and siorage fungi. However, as the seed loses humidity in the maturation process, the intraseminal conditions become inore favorable for storage fungi. So, at harvest time, a mixture of boll groups is associated with grain tissue, although field fungi are still more Grequently isolated. There are not definte limils with respect to the deterioration effects produced by field fungi and those produced by storage fungi (Chelkowski, 1991; Mass, 1991).

From the agricultural point of view, it may be stated, up to this moment, that the most significant toxigenic fungi belong to the Aspergillus, Fusarium, Penicillium and Alternaria genera (Wyatt, 1991; Piltet, 1998; Sweeney \& Dobson, 1999;).

\section{II.b) The genus Fusarium and its mycotoxins}

The genus exhibits a remarkable degree of variability in morphological, physiological and ecological attributes (Logrieco et al, 1999). Some are specifically pallogenic for vegetables, causing putrefaction in roots, death of planlules and cancer in mature plant lissues and other species are saprophytic on senescent plant malter, while there are even some those that cause degradalion of industrial products (Smith \& Moss, 1985).

Most Fusariun spp. are distribuled throughout the world and may be isolated from a wide variely of samples, especially in temperate climate zones, where they are considered the most important plant pathogens (Lacey, 1990; Langseth et ol., 1993). However, they are found in tropical regions too (Samson el al., 1995; Placinta el al. 1999).

A large number of species belonging to the genus Fusarium are capable of producing secondary toxic metabolites (De Nijs el al, 1996) and differ from the genus Aspergillus in that only a few species of the latter produce mycoloxins. De Nijs et al. (1996) reported that, out of more than 61 Fusurium species, 35 were capable to produce some mycotoxins. The main groups of Fusurium toxins commonly recognized in grains are trichothecenes, zearalenones, and fumonisins (Placinta et al., 1999). In addition, moniliformin, beauvericin, and fusaproliferin were also found in Fusurium infected cereal ears (Bollalico, 1998).

The ability to produce a particular mycoloxin may vary among isolates of the same species (Miller et al., 1991). Production of mycotoxins may therefore be used chemioraxononically to identify Fustrium isolates as a strain or a variety (Miller et al., 1991; Lori et al. 1992).

The trichothecenes are subdivided into four basic groups, with types $A$ and $B$ representing the most important members. The synthesis of the lwo types of trichothecenes appears to be characteristic for a paricular Fusarium species (Placinla el al. 1999). F. sporotrichioides, F. poae and $F$ equiseti are considered 10 be the inost important species producers of trichothecenes of Group A. (fundamentally $T-2$ and HT-2 toxins, diacetoxyscirpenol DAS, neosolaniol NS). Production of Group $B$ trichothecenes (deonynivalenol DON, 3-ACDON, nivalenol NIV and fusarenon-X FUS-X) is generally associated with $F$. graminearum, $F$ culmortan and Fo croookwellense (also zearalenone prodhcers) (WHO 1990, Lori et al., 1992; Miller, 1905). F. gramintearum, $F$ culmorum and F. croookpellense ( $=F$. cerealis (Cooke) Sacc.)also vary in pathogenicity. $F$ graminearum is regarded as the most virulent, allhough all three species can cause pathogenicity. Wheat, com and barley soem to be the grains that are mostly affected by these pathogens and these crops represent two thirds of the world production of cereals. Contamination with these Fusuriam toxins on rye, oats and triticale have also been repored (Chelkowski, 1989; Miller, 1995). Contamination Tricho-thecene-producing Fusarium spp. are destructive pathogens and attack a wide range of plant species. Trichothecenes appear to be examples of fungal toxins that can funcison as virulence faclors without strong host selectivity (Desjardins el al., 1996b; Desjardins \& Holun, 1997; Holun et al, 1998).

$F$ pericillioiles ( $F$ : moniliforme) is a serious pathoger of cereals such as maize and rice and its secondary metabolism includes the production of at least three mycotoxins, namely fumonisius, moniliformin and fusarin $\mathrm{C}$ (Abbas el al., 1993; Wicklow, 1994; Miller, 1995; Marasas, 1996; Moss, 1998). The production of fumonisins is quite 
widespread and a number of other species of Fusarium, including $F$ proliferatum, $F$ anthophilum, $F$ dlamini, $F$. napiforme and $F$ nygamai, were able to produce il (Nelson et al., 1992; Moss, 1998). The fumonisins $\left(\mathrm{FB}_{1}, \mathrm{FB}_{2}\right.$ and $\mathrm{FB}_{3}$ ) are also structural congeners of certain toxins produced by Alternaria alternata (Chen er al., 1992; Placinta et ol., 1999). It is also believed that fumonisins migh have an inportant role in the pathology of $F$. verticillioides on corn (Nelson ey al., 1993; Desjardins \& Holn, 1997), Other studies indicate a probable association between fumonisins production and high levels of virulenoe on corn, tomato and other plant buds (Desjardins el al. 1995).

\section{I.c) The geous Aspergillus and its mycotoxins}

The genus Aspergullus has a high metabolic versatility, a great ability to disperse ils conidia, and many of its species are capable of developing at low values of water activity $\left(a_{\mathrm{w}}\right)$. This facl allows them to grow in a wide range of natural subsirata and climatic conditions, and to be associated with deterioration of materials that are too dry to be attacked by other microorganisms (Gourama \& Bullermar, 1995b). Thus, the Aspergillus species conmonly affect food products and other materials such as wood, leather, lextile fibres, kerosene, paints, plastics, rubber, cement and pharmaceutical products (Smith \& Moss, 1985; Gourama \& Bullerman, 1995b). Some Aspergillus species are used in the manufacture of foods and compounds used in the food industry. Thus Aspergillus oryzae has been used in the manufacture of "koji", an intermediate product in the manufacture of oriental fernented foods. Aspergillus niger has been used for the produclion of citric acid.

Though nost of aspergilli are essentially saprophytic, other spocies may be allergenic, toxigenic and pathogenic for men and animals (Gourama \& Bullerman, 1995b).

- Aspergillus ochraceous ( $=$ A. alutaceus) is present in soil, grains and vegetables and in the process of decomposition. This species and olher related ones, as well as Penicillium verrucosum and Penicillium cyclopium (belong to P.aurantiogriseum/verrucosum complex) produce a group of structurally related inelabolites known as ocluratoxins (Prelusky et al, [994). The most important toxin in the group, ocluatoxin $\mathrm{A}$, has been isolated from a wide variety of plant products, cheese and tissues of animals that had eaten contaminated feed, though its phytotoxicity is not known (Fink-Gremmels el al., 1995; Desjardins \& Hohn 1997). A. ochraceous is also capable of producing penicillic acid.

Aspergiluts versicolor may be isolated from soil, mature cheese, cured meat or decomposing vegetables and is capable of producing sterigmatocystin (ST), an intermediary in aflatoxin biosynthesis, as well as cyclopiazonic acid (CPA). The latter, originally isolated from a Penicillium cyclopium culture during a routine screening of toxigenic fungi, may be also produced by different fungi found in agricultural products (A. versicolor, A. flavus, $A$. tamarii) or by fungi used in the production of fermented foods (Penicillum cantemberii and A. oryzae). CPA has been found to occur naturally in com, peanuts and cheese. Aspergillus clavatus may be found in animal excrements, soil and decomposing organic matter. Among olher toxic melabolites, uris species may synthesize patulin, also produced by species of Penicillium.

The species of Aspergillus belonging to the Section Flavi W. Gams el al.,1985(=A.flavus group.) are present in soil and contaminate a wide variety of agricultural products in the fields, slorage areas, processing plants and during distribution of such products. A. flavus, $A$. parasiticus and $A$. nomizs may produce aflatoxins (Gourama \& Bullerman, 1995b; Moss, 1998). The four main naturally produced aflatoxins are $B_{1}, B_{2}, G_{1}$ and $G_{2}$, with $B_{1}$ $\left(A F B_{1}\right)$ usually being the aflatovin found at the highest concentration in contaminated food and feed. The A. flavus strains vary from non-toxic to those which produce aflatoxins $\mathrm{B}_{1}$ and $\mathrm{B}_{2}$, while $A$. parasiticus inay produce aflatoxims $\mathrm{B}_{1}, \mathrm{~B}_{2}, \mathrm{G}_{1}$ and $\mathrm{G}_{2}$, A parasiticus tends to be more stable in its production of allatoxins than $A$. fawus (Gourama \& Bullerman, 1995b).

All aflatoxin producer fungi are soilborne microorganisms, but there are some differences in the occurrence pattem, (Diener et al., 1987; Domer et al., 1989). A. flays conidia are more common in air than in soil, and are generally found in tropical and mild regions. $A$. porasificus is adapted to warm environments such as tropical and sub-iropical regions and has been often found to be associated with soil. So, A. purasiticus is a more frequent contaminant for peanuts while A. favus contaminates corn. Wicklow, has reported (1994) hat sclerouia constitute the primary inoculum in cornfields. Nevertheless, high concenirations of aflaloxin are produced as a result of postharvest spoilage of commodities stored under warm moist conditions, and significant concentrations may also be produced in the field before lharvest (Payne, 1992; Moss, 1998; Placinta et al., 1999). Alchough aflatoxins have been reported to be phytotoxic, it is still necessary to determine the true role of aflatoxins in fungus-plant interaction (Desjardins \& Hohn 1997).

Biotransfonnation of aflatoxins $B$ in some animal species, including hunans that have consumed $A F B$, or $\mathrm{AFB}_{2}$ contaminated materials, results in the production of aflatoxins $M_{1}$ and $M_{2}$, which are exereted in milk and urine. AFM, has been widely found in a number of food products including infant formula, dried milk, cheese and yoghurt (Galvano ef al., 1996).

\section{II.d) The genus Penicillium and its mycotoxins}


Man in the production of foods and antibiotics Las used some species of Penicillium. P. roqueforti and $P$. canembertii are employed in the manufacture of cheese matured by fungi while $P$ : chrysogenum has been the main source in the penicilin industry (Smith \& Moss, 1985).

However, in moderale climate regions these are the dominant fungi associated with food decay. Although they are essentially saprophytic, some species show their ability to colonize certain fruils and vegetables. Thus $P$. digitatum and $P$. italicum are the green and blue fungi respectively found in citns fruit while $P$ expansum attacks apples and $P$. gladioli attacks bulbs, including onions.

The genus Penicillum contains many loxigenic species (approximately 100) and the range of mycotoxin classes produced is nuch broader than that of any other genus (Sweeney \& Dobson, 1998). Pitt (1991) and Pitt \& Leistner (1991) lis 27 mycotoxins produced by 32 species, which possess demonstrated toxicity.

As previously mentioned ochratoxin $A$ is produced not only by $A$. ochraceous but also by $P$. verrucosum and related species (Paurantiogriseum/ verrucosum complex). Penicillium species primarily produce ochratoxin in temperate climates while $A$. ochraceous strains are more comnonly associated with warmer climates (Sweeney \& Dobson, 1998).

$P$. cirrinum is widely distributed in the world in foods, decomposing plant marter and textile fibers and may produce citrinin. This mycoloxin may be also synthesized by $P$ verracosum strains present in cereal and by-products, and by P. expansum (Smidh \& Moss, 1985; Sweeney \& Dobson, 1998).

P. expansum, a fruit pathogen, may be isolated mainly from apples and pears. It can be a producer of citrinin as well as patulin (McKinley \& Carlion, 1991). The major source of patulin in the food supply is juice from apples infected with $P$. expansum (Pillet, 1998). Paurantiogriseumiverracosum complex (including $P$. cyclopium and others (Lund \& Frisvad, 1994; Sam-son et al., 1995) is also frequent in cereal and is capable of producing CPA and penicillic acid and even penitrem A. Some strains of $P$. purpurogenum, a soil fungus primarily associated with the deterioration of many substrates, produce rubratoxins. $P$. roqueforti isolated from blue cheese and from other products stored in cold, may produce PR toxin, isofumigaclavines and roquefortine (Smith \& Moss, 1985).

\section{ILe) The genus Alternaria and its mycotoxins}

The genus Alternaria is ubiquitous in the almosphere as well as in soil, seeds, and in agricultural commodities. It includes both plant pathogenic and saprophytic species that may damage crops in the field or cause postharvest decay of plant products in storage (Bottalico \& Logrieco, 1998). Some species may offen grow at low temperatures and may be associated with important damage to fruit and vegetables during transportation and storage in refrigeraled conditions (Magan \& Lacey, 1985).

Species of Alternaria are known to produce many metabolites, mostly phytotoxins, which play an important role in the pathogenesis of plants. Conidia of certain species, in particular $A$. alternata aggr. are abundant in the air, especially during cereal maturation and harvest. They are capable of producing several toxic metabolites in infected plants and/or in agricultural commodities, which can contaminate foods and feeds and elicit adverse effects in animals (Bottalico \& Logrieco, 1998). Besides at least 70 secondary melabolites can be produced by species of Aiternaria, only seven major toxins are known as possible food contaninants with a potential toxicological risk. These are tenuazonic acid (TA), alternariol $(\mathrm{AOH})$, altemariol mellyl ether (AME), altenuene (ALT), and altertoxin I, II, and III (ATX-I, ATX-II, ATX-III). The effects of environmental factors on the production of these mycotoxins have rarely been studied in detail (Bottalico \& Logrieco, 1998).

It has been demonstrated that AAL toxins (structurally similar to fumonisids) play an important role in the pathogenesis of A. alternata f.sp. lycopersici on certain tomato genotypes (Desjardins \& Holun, 1997).

\section{III) Control of food contamination with mycotoxins}

In the last thity years a tremendous expansion of research on mycotoxins has taken place. The knowledge gathered during these three decades has introduced us to a new era of inultiple discoveries (Stoloff, 1979). They include a better understanding of the biology of the involved fungi, the mechanisms that initiate the production of mycoloxins, their biosynthetic production paths, faclors and çonditions that determine fungal infection and colonization of a substrate, and the type and quantity of mycoloxin produced.

Perhaps the most important challenge today is to develop a package of control measures which, combined with the achieved knowledge might help in the development of cullural behaviours that would help to prevent or reduce contanination to manageable levels (Widstrom, 1996). With this aim in inind, provisional stralegies aiming to solve the present problen have been proposed while control measures intended to be definitive are being developed.

\section{III a) Provisional stratcgies}

III.a.1) Handling of conditions during the sowing and development of the plant

Fungal growth and inycotoxin biosynthesis are 
a consequence of an interaction between the fungi, the host (the plant) and the environment. In natural conditions there exists an interaction - more complex than laboratory condilions - between the toxigenic fungus and the substrate, no matter whether this association occurs in a field crop, in stored grain or in any other type of food. Variability of environmental conditions is added to the interaction of other biological factors, different from the fungal and plant genotypes, which may have influence on their growth and metabolism.

Assuming that the farmer is restricted to cultivate in a limited area, climatic conditions and the kind of soil are almost firmly fixed. The importance of the soil as a source of inoculum has been demonstrated (Widstrom, 1996). It was determined that some plowing techniques such as continuous crops favour the formation of sclerotia on the residues that remain in the fields after harvest, turning them into an inportant source of inoculum for the following years (Wicklow, 1994). The use of rotations - routinely recommended to obtain a good production - is also effective to reduce mycoloxin contamination of the crops (Wilson et al,. 1989; Widsurom, 1992). Elimination of weeds reduces waler consumption and removes an additional reservoir of fungal propagules. Processes of fertilization to obtain a good production are also adequate to diminish contanunation with mycotoxins.

The selection of the appropriate seed is of vital importance. The suggestions include use of seeds without fungi, use of hybrids that combine both adaptation to the medium and greater resistance 10 insects though the thickness of the cover (Widstrom $\varepsilon$ al., 1994). It has also been detected that certain cotton and peanut tissues, under certain conditions, reaci to the fungal attack producing considerable levels of certain antifungal compounds called phytoalexins. These substances are believed to have different effects on $A$. fluvus plyssiology such as to prevent fungal growth or 10 inlubit the first stages of aflatoxin synthesis (Santamarina et al, 1995).

The stress produced by excess water, drought, high temperatures, malnutrition and damage produced by rodents, birds or insects on the hosi plant may contribute significantly to increase the infection with toxigenic fungi in the spikes, damaging grain, transporting conidia and notoriously increasing the inyooloxin concentration (Moss , 1991).

In warm climates, conidia and selerolia of the $A$. Ravus group are usually present in the soil or on cereal plants providing an important inoculum souroe (Wicklow, 1994; Widstrom, 1996). It is generally affirmed that the process of infection occurs in the field where Aspergillus propagules may attack developing flower stigma (spikes in anthesis), or infect spikes from one to two weeks after their fertilization, increasing aflatoxin accumulation through grain maturation (Widstrom, 1996). Conidia may germinate and the germinative tubes penetrate the tissues of developing seeds, or the fungus may grow throughout the spike and eventually penetrate through lesions or ruptures in the pericarp and move through areas of the pedicel (Zummo,1991). The main place of grain invasion is apparently the same for grain matured in the field as for storage grain (Widstrom, 1996).

Delailed studies of associated climatic conditions have concluded that high temperatures and low humidity content during the development of some crops (corn, peanuts, cotton, elc.) are significandly correlaled to an important contanunation with aflaloxins (Widstrom et al., 1990; Gourama \& Bullerman, 1995b). Using an irrigation system, especially during the reproductive period of the plant (Jones, 1987), or adapting the sowing date for this critical period to coincide with the moment of minimum stress for lack of water could reduce the siress produced by drought (Widstrom el al., 1990).

In mild climates, after a series of rains, both ascospores and macroconidia of $\boldsymbol{F}$ graminearum and related species may infect wheat and corn with high humidity. They are more susceptible 10 infection during the first stages of anthesis (Snijders, 1994). If the lemperature later becomes moderate, an important contamination with DON may be produced, but if the temperature drops F.graminearum may produce zearalenove (Martin, 1993). In these cases there are not provisional solutions available and it is necessary to carry out strict control prior to storage.

Other fungi found in the soil or on decomposing plant material, for instance $P$. verrucosum and $A$. ochraceous, tnay also invade grain during development in the fields and later proliferate in storage if conditions are favourable, producing penicillic acid or ocluratoxin A (Miller, 1995).

In nature a fungal strain generally interacts with other microorganisms and the simultaneous growtl of different species usually occurs on a certain food. That may alter the metabolism of toxigenic fungi, compete for the necessary substrate, produce unfavourable conditions for the formation of mycoloxins, melabolise the toxins produced or even stimulate the produclion of one or more mycoloxins (Ellis er al., 1991). (These interactions will be discussed in the section on biological control).

Some biocides used in agriculture inhibit the formation of mycotoxins, while others may favour their biosynthesis. Up to now, only laboratory tests have been carried out (Zaika \& Buchanan, 1987, Gourame \& Bullerman, 1995b). Therefore, the application of herbicides and/or insecticides on growing plants inust be carefully evaluated.

Summarizing, serious programs for crop landling must include conditions that lead to the decrease of stress 
throughout the whole life of the plant. Also, frequent field inspections could help in early detection of drought stress, nutritional deficiencies or damage caused by insects, birds and rodents (Widstrom, 1996). This procedure may be critical to minimize the risk of an eventual contamination with mycotoxins.

\section{III.a.2) Handling of the product during harvest and storage}

It is imporiant to harvest as soon as possible once physiological maturity has been reached to maintain the grain quality and minimize losses. Inlact grains must be separated from foreign materials and broken grains, and dried until a moisture content is attained which prevents a later fungal growth ( 12 to $14 \%$ ) (Gourama \& Bullennan, 1995b). With favourable climatic conditions (especially temperature and humidity) grains may be dried in the fields, since artificial drying represents the most important expense of harvest.

Storage conditions play an important role in the physicochemical and microbiological quality of products. Humidity levels and temperature are the most important factors to be taken inlo account in the protection of stored grains from fungal growth and mycotoxin production (Clatterjee 1990; Ellis er al., 1991; Widstrom, 1996).

Humidity is essential for fungal grovth. It has been demonstrated that $A$. flavis, for example, will not invade stored cereal grains and oleaginous seeds with a relative luumidity of less than $70 \%$. At this relative humidity, wheat humidity content is approximately $13 \%$ and $7-10 \%$ for products rich in oil, such as peanuts and cotton (Ellis et al., 1991).

To control fungal growth, various studies have verified that temperature should be reduced to $5^{\circ} \mathrm{C}$ as soon as possible, especially in perishable products. However, the use of low temperatwes for the storage of agricultural products on a large scale is generally economically unfeasible.

The presence of insects in stored products indicales that the temperature and / or hunidity have increased in some "loot spots" since most insects are not capable of living and reproducing at low levels of lumidity and temperature. Good aeration is indispensable if one aims at keeping the grains cold and unifornly dry (Smityh, 1990).

Conservation of producis in plastic hermetic containers or sealed plastic folders under refrigerated conditions may maintain the humidity, especially on the surface, providing favourable conditions for fungal growth, thus precautions must be taken so as not to create a propitious environment for mycotoxin synthesis.

The gaseous atmosphere is another critical environmental factor that has its influence on fungal growth. For the conservation of some foods either storage in controlled atmosphere (CAS) or package in modified atmosphere (MAP) may be used (Elis et al., 1991). In CAS the gaseous atmosphere is modified to a desired level and kept at that level throughout the whole storage. Thus CAS has been applied to control the growth of $A$. flavis and the production of aflatoxins in peanuts stored in bulk (Pitt $e t$ al. 1993) and to prevent contamination by insects in stored graius (Ellis et al., 1991). MAP consists of packing food products in materials with a gaseous barrier, where the gaseous environment has been changed (generally increasing the $\mathrm{CO}_{2}$ content) to slow down breathing, reduce the microbiological growth and delay enzyroatic damage. Not many data with respect to the production of mycoloxins in foods packed in MAP are available yet. However, both CAS and MAP seem to be natural and econonical methods to control fungal growth as well as the production of mycotoxins in stored products.

\section{mb) Measures of definitive control}

Permanent solutions to the problem of contamination of grain and oleaginous seed with nycotoxins require time for their development and implementation. A definitive method for the control of pests and diseases is based on the creation of resistance in the host plant. A second alternative to achieve a solution in the long run has been the imposition of chemicals and / or conditions on the fungus, that inhibit mycotoxin production. Another means of control is the use of other microorganisms What might limit the growth of toxigenic fungi by different mechanisms. A last alternative might be genetic manipulation of the fungus to cause an interruption in its ability fo produce mycotoxins (Widstrom, 1996).

\section{III.b.1) Development of resistant hybrids}

From the beginning most of the research has been focused on obtaining plants resistant to aflatoxin contamiration (Zuber, 1977). A reliable identification of the type of plants resistant to fungal invasion was not possible until a uniform iroculation could be achieved under field conditions. It was also necessary to determine the most appropriate moment and inethod for inoculation and the time and way in which the samples had to be taken in developed grains (Widstrom, 1996). The subsequent screening revealed that even if evaluation and selection were difficult, the processes of infection and contamination would be under genetic control (Zuber \& Lillehoj, 1979). Various important sources of genetic resistance have recently been identified (Scott \& Zumuno 1988; Campbell et al., 1993) resulting in obtaining resistant germplasm (Scott \& Zummo,1992; McMillian el al., 1993). Therefore, the chances of finding and developing other sources of resistance are good and could, in the future, provide the cereal with defense against invasion of tovigenic fungi and subsequent production of mycoloxins (Sweeney \& Dobson, 1999). 


\section{III.b.2) Intervuption of the toxim production}

Interruption of the mycotoxin production processes may be also achieved by controlling the microenvironment where these fungi develop or by establishing methods of chemical or biological control.

III. 2.a) Chemical interference in the production of toxins A number of compounds that inhibit or suppress fungal growth and / or the fonmation of toxins have been tested. Most of them have been evaluated in stored products and consequently they have not been suggested as control agents for developing plants. Amnong these compounds are polassium metabisulfite, sodium bicarbonate, different phosphate compounds and several alkenals (Lebron et al., 1989; Montville \& Goldstein, 1989; Sharma el al., 1988; Zeringue, 1991). However, none of them has been recommended as an adequate control agent from a commercial point of view.

Compounds from different biological sources, as o-vanillin, volatile extracis and compounds of $\lambda$ zadirnchia indica leaves, spices and their oils, have also been tested as inhibitors of mycotoxin production (Bhatnager \& McCormick, 1988; Chatterjee, 1990; Ranjan et al, 1992; Zeringue \& Bha(nager, 1994).

Finally, compounds isolated from con itself have also been reported as having limiting activity against $A$. favus and aflatoxin production (Neurece \& Godshall, 1991; Neurece, 1992). Experiments by Brown et al. (1993), provide evidence that resistance to aflatoxun contanumation is related to metabolic activities in the living com embryo.

\section{WL.b.2.b) Interference or biological control}

In Nature, fungi not only interact with the host but also with many microorganisms present in the infection zone. In order to succeed, the fungus must attack the host and repel or compete with other organisms at the same time (Cook \& Baker, 1983). Therefore, the control of plant diseases using biological strategies may be achieved by regulating the pathogen population or excluding them Uurougl beneficial microorganisms (Gabriel \& Cook, 1990; Scott, 1995). It is desiderable, in general, that the introduced organisms are al ready part of the ecosystem and not part of exotic environment. The biological control offers less exposure to potentially toxic pesticides, fewer residues on the surface of marketed products and in consequence a lower risk of environmental pollution than chemical control as well as a more profitable cost-benefit relation (van Lenteren, 1992; Gloer, 1995).

Interest in new biological methods of preservation has increased in recent years, supported by investigations that point out that those antagonistic organisms or their antimicrobial metabolites might act as natural preservatives to control toxigenic fungal growth (Schillinger et al., 1996).
Thus, tests of intraspecies or interspecit competition have been made. The first type of biocon petitive control involves the use of non-toxigenic strait isolated from the same habitat where the toxigenic strail are found, either as agents of growth limitation and / or: indibitors of mycotoxin production. The strain stability is fundamental criterium in the selection of this type , biocontrol agent (Colty, 1990). In these tests, carried out $i$ greenhouses or in the fields, atoxigenic strains (highl compelitive) were inoculated together with th corresponding toxigenic strains in corn ear (Brown \& Cott 1991), peanuts or cotton bolls (Colty, 1990), or roots i developing plants (Chourasia \& Sinla, 1994), or added 1 the soil where cereals or oleaginous plants were growin (Domer et al, 1992; Cotyy, 1994; Dorner et al, 1998: Darn et al. 1999). In most cases the atoxigenic strain diminisht mycoloxin contamination of the seeds when it was applie simultaneously with, or previously to the toxigenic strai (Cotty, 1990; Brown \& Cotty, 1991; Dorner el al. 199: Clourasia \& Sinda, 1994; Coliy, 1994). However, differena were found in the ability of atoxigenic strains to preve inycoloxin production, especially of aflatoxins (Colty , Blatnager, 1994; Dorner ef al. 1998; Domer et al., 1999 Data also indicated that a higher degree of control migl be achieved when plols or fields were retreated wil bioconirol agents in subsequent years (Domer et al., 1998 Interspecies competition tests, in which toxigen strains of Aspergillus, Fusurium or Penicillium we confronted in the laboratory, in greenhouses or in the fielt with different biocompetitive agents (also isolated fro: the same ecological niche as the organisin to be controlled presented more variable results (Misaghi el al., 1995 Among them different species of filamentous fir. (Aspergillus niger, Aspergillus auriconus, Penicillit. sp., Fusurium sp., Trichoderma sp., Rhizopus sp., ete Elirlich el al., 1985; Devi \& Polasa, 1987, Wicklow et a 1987; Cuero et al, 1988; Cloudliary, 1992; Widstrom et a 1995) and even a yeast (Pichia guillermondii) (Schilling et al., 1996) could inhibit the development of toxigenie fun and/or the production of mycotoxins or they could influen the fungal patterns of colonization in vitro Marin el a 1998a, Marin ei al., 1998b; Marin et al. 1998c).

In greenliouse and field lests a significa decrease in infection of corn spikes vill $A$. flavus, and the subsequent production of aflatoxins, due to inoculatir with $F$ moniliforme was reported (Wicklow et al., 198 Widstrom et al., 1995). The reduction in the mycotox production by competition between Aspergillus al Fusarium sp. was smaller in the field than in the laborato (Ehrlich et al., 1985; Widstrom el al., 1995). Besides, it h also been suggested that the prospective use of other fung strains as competitors of toxigenic fungi is not promisin It may probably be due to the fact that, in Nature, the me 
appropriate time and means of infection are not the same for both fungi (Widstrom et al., 1995).

In the last few years the objective of different investigations was to study the influence exerted by exonetabolites of various microorganisms (other fungi and bacteria) on the growh and production of mycotoxins by certain fungal strains. Inlubition of growth of $A \cdot f l a v u s$ and A. parasiticus was produced by metabolites of Rhizopus microsporus, $R$ arrhizus and Neurospora sitophila (Nout, 1989; Lanciolli \& Guerzoni , 1993; Nout, 1995). Similar effects were produced on Penicillium roquefort by volatile antagonistic compounds of Pichia anomala (Bjomberg \& Schnurer, 1993). Substances produced by other aspergilli (A. niger, A. oryzae and $A$, tanmarii) also inhibited the growh of A. flavus, A. ochraceous and their mycotoxin production (Slianta \& Rati, 1990; Shanta et al, 1990; Paster et al., 1992, Sardjono el al., 1992).

Similarly, there have been attempts at biccontrolling toxigenic strains with several bacteria. Some lactic acid bacteria (LAB) have been rested. In the majority of repors it was postulated that the cause of this inhibition was the action of a metabolite prescnt in the culture supernatants of laciic bacteria (Gourama \& Bullerman , 19950). It was reported that the effect of two strains of lactic bacteria (Laclococcils loctis and Streplococeus termophilus), with antifungal activity against $A$. purasiticus, A. fumigatus and Rhizopus sp. The activity was produced by a compound probably of polypeptide nature since its activity was destroyed by the action of proteolytic enzymes (pronase $\mathrm{E}$ and trypsin) (Batish el al, 1990; Batish et al., 1991). The culture supernatant of a mixhure of Lactobacillus species inhibited the production of aflatoxins by A. parasiticus also reducing the fungal growth (Gourama \& Bullermar, 1995c). Tlus inhibicion was probably due to a metabolite of molecular mass $>6000 \mathrm{D}$. Gourama \& Bullernian, (1995a). Karuinaratne ef al., (1990) have reported that several Lactobacillus spp. Strains totally inhibited the conidial germination of aflatoxigenic fungi. Other compounds produced by Lactobacillus spp. only inhibited the biosynthesis of aflatoxins $B_{1}$ and $G_{1}$ by $A$. parasilicus (Karutnaratne el al. 1990) and were to be sensitive to the action of proteolytic enzymes (trypsin and a-chynotrypsin) and of heat (Gourana \& Bulleman, 1997).

The antimicrobial activity of other bacteria annong toxigenic species of Aspergillws, Fusarium and Penicillinm was studied (Motomura \& Hirooka, 1996). Among them strains of Bacillus subtilis produced subsiances which suppressed the growll of loxigenic $A$. parasiticus and $A$. flaw as and blocked the synthesis of aflatoxins (Kimura \& Hirano, 1988; Ono \& Kimura, 1991). Some of unese melabolites had peptide characteristics (Ono and Komura, 1991). In other cases, certain strains of $B$. subihis were aclive against the development of Fusurimm verticillioides, A. parasiticus and Penicillium expansum (Motomura \& Hirooka, 1996). Another bacterial strain, identified as Pseudomonas cepacia, completely inhibited A. flavus growh in synthetic media and reduced the damage produced in colton bolls by this fungus. This was the first report of an antagonistic bacterium capable of reducing the damage caused by a toxigenic fungus on a plant in ule fields (Misaghi et al, 1995).

Bacteria of the Streptomyces genus are very abundant in soil and they are included in the literature within the main producers of bioaclive compounds and extracellular enzymes. Their effectiveness has been demonstraled against bacteria, fungi, some protozoa and nematodes (Dicklow ei al., 1993; Coelho et al., 1995; TrejoEstrada et al, 1998). Subsiances produced by Streptonyces spp. strains that could inluibit growth of toxigenic fungi or their mycotoxin production are very few. A Streptomyces sp. strain produced a new compound that inhibits the synthesis of aflatoxin $B$, by A. parasiticus (Ono ef al., 1997). This compound, a polyalcolol of 63 carbon atoms called aflastatin $A$, did not present any effect on the fungal developnent.

As part of a screening of Sireptonyces strains isolated from soil of cereal crop, a strain with activity inhibiting conidia germination of A. purasiticus (aflatoxin producer), Fusarium graminzarum (deoxynivalenol and nivalenol producer) and Fusaritum tricinctum (T-2 and HT2 coxins producer) was selected. This effect was due to the presence of ancifungal substances (Borghi et ol, 1988; Fulgueira el al., 1989; Borghi el al., 1992). In experiments carried out on developing wheat plants (in greenhouse) it was determined that the Streptomyces sp. strain stopped fungal colonization and its effects: decrease in weight of the wheat grains caused by $F$ graminearum and its mycoloxin produclion (Fulgueira el al., 1992, Fulgueira $\ell$ al., 1996; Fulgueira, 1998). Subsequent studies demonstrated that the imhibiting activity was sensilive to proteolytic enzymes (promase and elastase) and to heat and the substance could have a molecular mass beiween 8 and $20 \mathrm{kDa}$. Up to now the majority of experiments on the control of toxigenic fungi lave been developed for corn, peamuts and cotton plants, and different Sreptomyces spp. have been successfully used to decrease damage produced by pathogenic fungi soilborne in some cereals and cruciferous plants (Tahvonen et al. , 1994). These reports represent the first finding corresponding to the reduction of the effect produced by toxigenic fungi in wheat plants achieved by the application of an antagonist strain of Streptomyces sp.

\section{IIL b.3) Genctic manip ulation of the torigenic fungi \\ Information about mycoloxin syuthesis slowly began to appear in the literature during the 1970s (Papa,}


1979). Work on the biosynthetic pathway of aflatoxin $B_{\text {, }}$ began using $A$. parasiticus as fungal model, developing new strategies for identifying genes and pathways for different aflatoxins (Bhatnager ef al., 1989; Bhatnager el al., 1991).

A wide range of Aspergillus spp. can synthesize a precursor of aflatoxins, slerigmatocystin. The first step in the biosynthesis of sterigmatocystin/aflatoxins is catalyzed by a type I polyketide synthase (Feng \& Leonard, 1995). In contrast with most polyketide synthases that use acetate as a precursor, the precursor for the aflatoxin/ sterignatocystin enzyme is hexanoale (Brobst \& Toivnsend 1994). The synthase reaction product and furst stable intermediate in the pathway is norsolorinic acid, which undergoes a complex series of modifications 10 yield sterigmatocystin and, finally aflatoxin. Up to now, many of the genes involved in the sterigmatocyslin biosynthetic pathway have been cloned and their functions identified. Studies in Aspergillus nidulans have shown that the gene encoding the polyketide synthase ( $p k s S T$ ) is part of a gene cluster contaiuing at least 25 pathway-related genes (Brown el al., 1996). This gene cluster occupies a 60 -kb region and contains genes for regulatory faciors in addition to all of the required pathway enzymes. The genetics of the aflatoxin biosynthetic pathway have also been ehicidated. Mapping studies indicate that all the cloned genes involved in the aflatoxin biosynthetic pathway are contained within a $75-\mathrm{kb}$ cluster located on a single chromosome in A. flavus and A. parasiticus (Tmil el al., 1995; Yu et al., 1995; Brown et al., 1996; Silva et al., 1996; Desjardins et al., 1997). Genetic studies on aflatovin biosynthesis in $A$. nidulans, led to the cloning of 17 genes responsible for 12 enzymatic conversions in the AF/ST pathways. Pathwayspecific regulation is by a $Z n$ (II) 2 Cys 6 DNA - binding protein that regulates aflatoxin biosynthesis but there is a clear link between development and aflatowin biosynthesis (Payne \& Brown 1998).

The biosynthesis of trichothecenes by Fusarium spp. proceeds from the hydrocarbon trichodiene througls a complex series of steps to Irichothecenes such as DAS, DON and T-2 coxin. The details of trichothecene biosynthesis have been established through experiments with a number of Fusarium sp. (Desjardins el al., 1993). In common with the biosynthetic genes for aflatoxins and many other inicrobial antibiotics, tricholhecene pathway genes in Fusarium are closely linked and conslitute a gelle cluster (Holin et al. 1995). At least 10 palhway genes involved in trichothecene biosynthesis have been identified witlun a $23-\mathrm{kb}$ region of chromosomal DNA in $F$. sporotrichioides (Holnn et al., 1998). The cluster contains Tri5, the gene encoding trichodiene synthase, wlich catalyzes the first step in tricholhecene biosynthesis (Desjardins \& Holn 1297). Recent investigations of the
Lrichothecene pathway gene cluster have provided new information concerning the transcriptional regulation of pathway gene expression ( $\mathrm{Tri}$ ) and the transport of pathway products (Tri2). A trichothecene resistance gene (Trir) has also been identified in $F$. sporotrichioilles. Expression of microbial trichothecene resistance gene in wheat map provides a means for further invest igating the importance of trichothecenes in Fusarium wheat head scab (Holun et al., 1998).

In the case of fumonisins, their structural similarity to the long chain sphingolipid bases suggests that their biosynthesis may be similar to sphingolipid biosynthesis. Genetic crosses using naturally occurring fumonisin production variants have identified the fumonisin biosynthetic genes in Gibberella fujikuroi (Fusarium verticillioides). Three genes have been identified, fumI, fum 2 and fum 3 . These genes are linked and appear to form a fumonisin biosynthetic gene cluster on cluromosome 1 of Gibberella fujikuroi (Desjardins el al., 1996n, Desjardins \& Holn 1997).

Molecular genetic analysis of the biosynthetic pathways of other mycotoxins of Fusurium, Aspergillus and Penicillium is not very far advanced.

Much progress has been made on the molecular characterization of the genes involved in the biosynthesis of various mycotoxins. This knowledge is useful in order 10 understand the organisalion, regulation and expression of these genes, the physiological factors controlling these processes and the role of each mycotoxin in the plant pathogenesis. In addition it aids improvement of molecularbased detection methods for mycotoxins and mycotoxigenic fungi in food systens. Also, these findings may allow the development of measures for the biological control of toxigenic fungi and the development of genetically engineered resistant crop plants (Siveeney \& Dobson 1999).

The availability of a variety of molecular tecluniques has made possible precise studies on genetics affinity and phylogeny of populations of toxigenic fungi. Correct identification by morphological, genetical, and molecnlar approaches as well as toxicological characterization of toxigenic species that colonize crop plants and food is a major task in order to assess the potential risks of inycotoxin accumulation and prevent aninal and human mycotoxicoses (Logrieco el al., 1999). 


\section{REFERENCIAS}

Abbas, H.K., Duke, S.O. \& Tnnakn, T. (1993). Plıytotoxicity of fumonisins and related compounds. J. Toxicol. Toxin Rev. 12: 225252 .

Agnrwal, V.K. \& Sinelnlr, J.B. (1987). Principlis of seed pathology Vol L-2, CRC Press, Florida.

Basilico, J.C. (1995). Micoloxinas en alimentos. El ricsgo sobre la mesa, Celltro de Publicaciones (Universidad Nacional del Litoral), Santa $\mathrm{Fe}$.

Batlsh, B.K., Ram, L. \& Grover, S. (1990). Studies on environnental and nutritional factors on production of antifingal substauces by Laciobacillus acidophilus. Royal Food Microbiol. 7: 199-206.

Bntlsli, B.K., Rani, L. \& Grover, S. (1991). Interaction of Streplococcus lactis subsp. dlacelylactis DRC-1 with Aspergillus parasiticus and $A$. firmsgants in milk. Cult. Dainy Prod. J. 26(1): 1314.

Bhatnager, D. \& MrCornlck, S.P. (1988). The inhibilory cfiecl of neem (Azadirachra indica) leaf extracts on aflatoxin synthesis in Aspergillus parasilicis. J. Aul. Oil Chem. Soc. 65: 1166-1168.

Dhatnager, D., Cleveland, T.E. \& Lllichoj, E.B. (1989). Enzymes in late slage of aflatoxin $B$, biosymhesis: Strategies for identifying pertinent genes. Mycopalhologia 107: 75-83.

Bhatnager, D., Clevelnnd, T.E. \& Kingston, D.G.I. (1991). Enzymological cvidence for separale pathways for aflatoxin $B$ and $B$, biosynthesis. Biochenisiry 30: $4343-4350$.

Bjornberg, A. \& Schnurer, J. (1993). Inhibition of growth of grain storage molds in viero by the yeast Plchia anomala (Hausen) Kurlzman. Can. J. Microbiol. 39: 623-628.

Borght, A.L., Fulgueirn, C.L. \& Braralenti, B.I.C. de. (1988) Inhibición de Frlsaryum gramlnearn!" por una cepa de Streptomyces sp. Bol. Micol. 4(1): 237-242.

Borghi, A.L., Fulguelra, C.L. \& Bracalentl. B.J.C. de. (1992). Antagonism between loxigenic fungi and a strain of Sirepromiyces sp. Rev. Microbiol. 23(3): 194-198.

Bottalico, A. (1998). Futsorium diseases of cereals: Species complex and related mycoloxin profiles, in Europe. J. Plan Paurol. 80(2): 85-103.

Bottallco, A. \& Logreco, A. (1998). Toxigenic Allernaria Species of Economic Importance. In: Mycoloxins in Agriculture and Food Safely, edited by K.K. Sinlıa and D. Bliatnager. Marcol Dekker Inc. New York. pp; 65-108.

Brobst, S.W. \& Townsend, C.A. (1994). The potential role of fally acid initiation in the biosynthesis of the nungal aronatic polyketide aflatoxin $B_{1}$. Can, J. Chem. 72: 200-207.

Brown, R.L. \& Cotty, P.J. (1991). Reduction in aflatoxin content of maize by aloxigenic strains of Aspergillus havus. J. Food Prou. $54(8): 623-626$.

Brown, R.L., Colty, P.J., Cleveland, T.E. \& IVidstrom, N.W. (1993). Living maize embryo influences accunulation of a flatoxin in maize kernels. J. Food Prol. 56: 967-971.
Brown, D.IV., Yu, J.H., Kelkar, H.S., Fernnndes, M., Nesbltt, T.C., Keller, N.P., Adams, T.H. \& Leonard, T.J. (1996). Tiventyfive coregulated Iranscrips define a sterigmalocystin gene cluster in Aspergillus nidulans. Proc. Natl. Acod. Sci. USA 93: 1418-1422.

Campbell, K.WY., White, D.G. \& Tonuan, J. (1993). Sources of resistance in $\mathrm{F}_{\text {, con hybrids }}$ to ear rol caused by Aspergillus Ravis. Plant Dis. 77: 1169-1171.

Chatterjee, D. (1990). Inhibition of rungal grouvh and infection in inaize grains by spice oils. Lell. Appl. Microbiol. 11: 148-151.

Chelkowsk. J. (1989). Formation of mycoloxins produced by Fissorim in heads of wheal, triticale and rye, In: Fusarmm mycoloxins, Taxonomy and Pathogenecity, Elsevicr Science Publishers, Ansslerdnn, pp. 63-84.

Chelkorvki, J. (1991). Fungal palhogens influencing cereal seed quality at harvest. In: Cereol Graiı, Mycoloxins, Fungi and Qualıly in Drying and Storagc, edited by J. Cletkowsky, Elsevier Science Publishers, Austerdam, pp: 53-66.

Chen, J., Mlrocha, C.J., Xie, W., Hogge, L. \& Olson, D. (1992). Production of the mycotoxin numonisin $B$ by Allemaria allernata C.sp. lycopersici. Appl. Environ. Mierobiol. 58: 3928-3231.

Choudhary, A.K. (1992). Influence of microbial co-inhabilants on aflatoxin synthesis of Asperg/llus havils on maize kemel. Lell. Appl. Microbiol. 14: 143-147.

Chourasia, H.K. \& Sinha, R.K. (1994). Potential of the biological control of aflatoxin conlamination in developing peanut (Arochis hypogoea L.) by aloxigenic strains of Aspergillus Ravils. J. Pood Sci. Techuol. 31(5): 362-366.

Coelio, R.R.R., Lupes, A., de Azevedo Soares Semedo, L.T. \& Stcele da Cruz, F. (1995). Culture filtrates of Actinomycetes isolated from tropical soils inlibit Trypanosomo crizi replication in vitro. Rev. Microbiol. 26(4): 307-313.

Cook, R.J. \& Baker, K.F. (1983). Nature and Praclice of Biological Control of Plant Pathogens, St. Paul. American Phytoparhological Sociely, Si paul MN.

Cotty, P.J. (1989). Virulence and cullural characteristics of I ivo Asperglllus favtus strains puthogenic on collon. Phytopathology 79: $808-814$

Cotty, P.J. (1990). Effects of aloxigenic strains of Aspergillns navis on aflatuin contamination of developing coltonseed. Plant Dis. Marclı 1990: 233-235.

Cotty, P.J. (1994). Infuence of ficld applicalion of an aloxigenic strain of Aspergillus flavis on dic populations of Aspergillus flavis infecting colton bolls and on the aflatoxin content of collonseed. Phyropalıology 84(11): 1270-1277.

Colty, P.J. \& Bhalnnger, D. (1994). Variability among atoxigenic Aspergllins flatus strains in ability 10 prevent aflaloxin contanination and production of aflatoxin biosynshetic pathway enzymes. Appl. Environ. Mlicrobiol. 60: 2248-2251.

Cotly, P.J., Bayman, P., Egcl, D.S. \& Elias, K.S. (1994). Agricullure, aflaloxims and Aspergillhs, ln: The gentus Aspergillus, ediled by K.A Powell, Plenum Press, New York. 
Cuero, R, Smith, J.Z. \& Lacey. J. (1988). Mycotoxin formation by Aspergillus flavus and Firsarium grommeanun in irradialed maize grains in the presence of olher fungi. 3. Food Prot. 51: 452.456.

Drvles, N.D. \& Dlener, U.L. (1987) Food and beverage mycology, edited by L.R. Beichat, Van Nos! rand, Reinhold, New York, pp. $517-538$.

De Nijs, M., Rombouts, T. Noterman, S. S. (1996). Fusarinm molds and their mycotoxins. J. Food Sallety 16: $15-58$.

Desjardins, A.E. \& Hohn, T.M. (1927). Mycotoxins in plant pathogenesis. Mol Plani - Microbe Intcracl 10(2): 147-152.

Desjardins, A.E., Hohn, T.M. \& MrCornick, S.P. (1993). Trichothecene biosynthesis in Fusarium; Chemistry, geneties, and significance. Mictobiol. Rev. 57: 214-222.

Desjardíns, A.E., Plather, R.D., Nelson, T.C. R Leslle, J.T, (1995). Genelics analysis of fumonisin production and virulence of Gibberella fijikaroi maling population A (Fiscrmm moniliforme) on maize (Zea mays) seedlings. Appl. Environ. Microbiol. 61:79 86

Desjardins, A.E., Platiner, RD. \& Proctor, R.H. (1996). Linkage among genes responsible for fumonisin biosynuesis in Giberella frijkaroi mating population. Appl. Environ. Microbiol. 62: 25712576.

Desjardins, A.E., Proctor, R.H., Bai, G., McCormick, S.P., Shaner, G., Bucchley, G. \& Honh. T.M. (1996 b). Reduced virulence of trichothecene=non producing nutants of Gibberella zeae in wheat field tests. Mol. Plant-Microbe nnerat. 9: 775.781.

Desjardins, A.E., Platuer, R.D. \& Nolson, P.E. (1997). Production of fumonisin $\mathrm{B}_{1}$ and moniliformin by Giberella fimkinros from rice from various geographical meas. Appl. Environ. Microbiol. 63: $1838-1842$.

Devi, G.R. \& Polasa, H. (1987). Interference in toxin production among toxigenic Aspergllhs species. J. Stored Prod. Res. 23, 149150.

Dicklow, M.D. Acosta, N. Zuckermsn, B.M. (1993). A novel Sireptonyees species for controlling plant-parasitic nemalodes. J. Clum. Ecol. 19(2): $159-173$.

Dlener, U.L., Cole, R.J. \& Hill, R.A. (1987). Epideniology of aflatoxia formation by Aspergillus fowns. Ann. Rev. Phyopatiol. 25: $249-270$.

Dorner, J.WV, Cole, R.J., Sanders, T.H. \& Blankenghlp, P.D. (1989). Interrelationship of kernel water activity, soil temperature, malurity, and phytoalexin production in preharvest aflatoxin contamination of droughi siressed peanu1s. Mycopalhologia 105: $117-128$

Dorner, J.W: Cole, R.J. \& Blankeshlp, P.D. (1992). Use of a biocompetitive agent to control preharvest aflatoxin in drought sluszed peanuls. J. Food Prot, 55(11): $888-892$.

Dorner, J.W., Cole, R.J. Blankenship, P.D. (1998). Effect of inoculum rate of biological control agents on preharvest aflatoxin contanination of peanuts. Biol. Control. 17(3): 171-176.

Dorner, J.W., Cole, R.J. \& Wicklow, D.T. (1999). Aflatoxin reduction in corn through field application of conpetitive Fun Food Prol. 62(6): 650-656.

Ehrlich, K., Ciegler, A., Klich, M. \& Lee, L. (1985). T, competition and mycoloxin production on corn. Experienti. $691-693$.

Ellis, W.O., Smith. J.P., Simpson, B.K. \& Oldham, J.I. (I Afnoxins in food: occurrence, biosynlhesis, effects on organ delection and methods of control. Crit. Rev. Food Sci. Nutr. ? 403-439

Feng, G.H. and Leonard, T.J. (1995). Claracterization o poliketide synthase gene ( $p k s L S$ ) required for aflatoxin biosym in Asperghins parnsincis. J. Bacteriol. 177. 6246-6254.

Fink-Cremunels, J., Blom, M.J, Woutersen van Nijna F.M.A., Jnhn, A., de Groene, E.M. \& Horbuch, G.J.M.J. (I Biolransfomalion processes in the ctiology of ochraloxicosi: Molecular Approucles in Food Safely; ediled by M. Eklund. Richard \& $k$. Mise, Alaken Forn Collins CO. pp. 107-121.

Pulgueira, C.L. (1998). Comportamiento de hongos loxicogé en el eccsistena suilo. Ph. D. thesis, Universidad Nacional de Ro Rosario. Repiblien Asgentina.

Fulgueira, C.L., Borghl, A.L. \& Bracalenti, B.J.C. de. (1: Inhibicion de Aspergilhs parasilicus NRRL 2999 por una cel Sileptonlyces sp. Rey. Microbiol. 20(2): 215-219.

Fulguclra, C. L.. Borghi, A.L., Gattuso, M.A., Gattuso, Bracalcni, B.J.C. de. (1992). Interacción de longos toxicogé con una cepa de Streptonyces sobre el desarrollo de plantas de Bol. Micol, $7(1-2) ; 7.12$.

Fulgucirn, C.L., Borght, A.L., Gatuso, M.A. \& Di Saph (1896). Enects of the infection of loxigenic hungi and an antaE Sirepronjeces strain on wheat spikes. Mycopathologia 134: 142.

Gahriel, C.K. \& Cook, R.J. (1990). Biological control of ; pathogens, American Phyiopathological Socialy, St Paul MN

Gulvano, N., Galofaro, V. Galvano, G. (1996). Occurremer stability of aflatoxin $\mathrm{M}_{1}$ in milk and milk products: $A$ wold reviev. J. Food Prol. 59: 1079-1090.

Gams, W.; Chrlalensen, M.; Onions. A.H.; Pill,J.l.; Sam R.A. (1985) Infrageneric coxe of Aspergillus. In : R. Samse 3.Pilt (Eds.) Advances in Penicilliun and Aspergillos Systeru. Nato ASI Serics, Series A: Life Sciences Vol 102.. Plemum $F$ N.York, pp. \$5-62

Gloer, J.B. (1995). The chemistry of fungal antagonism defense. Can, J. Bol. 73(1): S1265-S1274.

Goursma, H. \& Bullerman, L.B. (1995 a). Antinycolic antiaflatoxigenic effect of lact ic acid bacteria: A revietv. J. . Prol. 58(11): 1275-1280.

Gourama, H. Bullerman, L.B. (1995b). Aspergilins $\Omega$ and Aspergilhus parasiticus: aflatoxigenic fungi of concern in: and feeds. A review. J. Food Prol. 58(12): 1395.1404.

Gouramn, H. Bullermon, L.B. (1995c). Inhibition of gr and afatoxin production of Asperghlhs gams by Lactobac 
species, J. Jood Prot. 58(11): $1249-1256$.

Gourama, II, \&ullermun. L.B. (1997). Anli-aflatoxigenic nctivity of Laclobacillirs casel psendoplaniarnm. Int. J. Food Microhiol 34(2): 131-143.

Jalu, T.M., Desjundirns, A.E., MeCormlck, S.P. \& Proctor, R. (1995). Biosymbesis of iricholhecenes, genelic and nolecular aspects. In: Molecular Approaches to Food Sofely, ediled by M. Eklund, J.L Richard \& K. Mise, AJaken, Fort Collins, CO, pp. 239. 245 .

Ilolun, T.M., NcCormirk, S.P., Alerander, N.J., Desjardins, A.E. \& l'roctor. R.II. (1998) Funclion and biosynthesis of trichohewenes produced by Fusarinm species. Mol. Gen. Hostspesific Tox. Plant Dis. 13 PG: 17-24.

LLudson, II.s. (1986). Fungal Biology. Edward Amold. London.

Jones. R.K. (1987). The infmence or cultural praclices on minimizing the development of nosoxin in field maize, In: Aflaloxin in maize. sdited by M.S. Zuber, E.E. Lillehoj \& B.L. Renfro, CIMMYT, México. Pp. 136-144.

Karulnaratne, A., Wezenberg, E. d Dullerman. L.B. (1990). Inhibition of nold growh and aflatosin production by Lacrobscilus spp. J. Food Prol. 53: 230-236.

Kinurs, $\boldsymbol{N}$ \& Rirano, S. (1988). Inhibitory sirain of Bocillus swbilis for growth and aflatoxin-production of aftatoxigenic fungi. Agric. Biol. Chem. 52: 1173-1179.

Kozakicwict, Z. (1989). Aspergillus species on stored prodtucts. Mycol. Papers $161: 1=18$.

Lancey, J. (1990). Mycoloxins in UK cereals and their control. Aspecis. Appt. Biol. 25: 395-405.

Laclatiova, A., Vargovń, M. Laciak, V. (1995). Somc mycotoxins causing health probtems in farm animals. Biol. Brat. 50(3): 293.295 .

Lanelott, R. \& Guerionl, M*E. (1993). Intibition of Aspergilhs fowns by volatile nelaboliles of Rhizopus arrhizus. Food Mierobiol. 10: 367.377 .

Langset, W, Stenwing, H., Sogn, L. Mo, E. (1993). Groml of moulds and production of mycotoxins in wheat during drying and storage, Soil Plant Sci. 43: 32-37.

Lebron, C.I, Molins, R.A., Whalker, H.W., Kraft A.A. Stalur, HM. (1989) lubibilion of mold growh and nycotoxin production in ligh-moisture corn treated with phosphates. J. Food Prot. 52: $329-336$

Logrieco, Ans Allomire, C., Mule, G. Morelti, A. (1999). Recen! Rez. Devel. Nicrobiol. 3: 135-145.

Lori, G.A. Corrmazn, M.R., Vlolante, A., Rlzro, R. \& Alippi, H.E. (1992). Fusarim spp. en Irigo, capacidad loxicogénica y quimiolaxonomia de las cepas aisladas en la Argenlina. Agronomie 12: $459-467$.

Lund, F. Frisvad,J.C. (1994). Chemalaxonomy of Penicillinm aurauliogriseum and related species. Mycol. Res .98: 481-492

Magan, N. \& Lacey, J. (1985). The effect of woter activity and lemperature on myootoxin prodiction by Allesmatra alremola in cullure and on whed grain, In: Tricholhecenes and olher myeotoxins, cdiled by J. Lacey, John Wiley \& Sons Lid., London.

Marasas, IV.FO. (1996). Fumonisins: hisiory, svorld-wide occurrence and impace. In: Fumonisins in Food, ediled by L.S. Jackson, J.W. DeVries \& L.B. Bullennan, Plenum Press, New York. pp 1.17.

Marin, S., Sanchis, V., Armum, F., Ramos, A.J. Mugnn, N. (1998a). Colonisation and competiliveness of Aspergillus and Peniclllum species on maize grain in the presence of Fusarium monilforme and Fiesarlin prolifercum. Int. J. Food Microbial. $45(2): 107-117$.

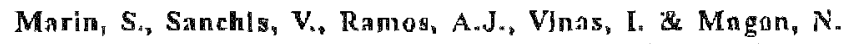
$(1998 b)$. Environmental [actors, in vilro interactions, and niche overlap between Fusarinm monilforme, Fusarinm prolfferanu and Fusarfum graminearam, Aspergilhis and Pemcillom species from maize grain. Mycol. Res. $102(7): 831-837$.

Marin, S., Sunchis, V., Rull, F., Ramos, A.J. \& Magan. N. (1998c). Colonisation of maize grain by Fusarium momliforme and Fisaring probleratum in the presence of competing fungi and their impact on fumonisin production. 3. Food Protect. 61(11): 1489.1496.

Mariln, R.A. (1993). Seasomal variability in Fusorinm species associaled with wheal and barley hends. Can. J. Bol, 35: 247-251.

Mckunley, E.R. \& Corlton, W.W. (1991), Patulin. In: Mycotoxins and Phyloalexins, ediled by R.P. Shomn \& D.K. Salunkhe, CRC Press, Boca Ralon. FL. pp. 191-236.

MeMillian, W.W., Widstrom, N.W, \& Wilson, D.M. (1993). Regisiration or GT-MAS:gk naize gemplasm. Crop Sci. 33: 882,

Miller, J.D. (1995). Fungi and mycoloxins in grain: inuplications for stored producl pasearch. J. Stored Prod. Res. 31)(1): 1-16.

Miller, J.D., Greenluald, R., Wang, Y, Lu, M. (1991). Trichothecene chemalypes of three Fisarimm species. Mycologia $83: 121-130$.

Mlsnghí, I.J., Colty, P.J, \& Decinnnc. D.M. (1995). Bacterial antsgonisis of Aspergillus fewns. Bioconirol Sei. Technol. 5: 387 392.

Montville, T.J. Goldstein, P.K. (1989). Sodium bicarbonate inhibition of allatoxigenesis in corn. J. Food Prot. 52: 49-48.

Moss, M.O. (1991). Mycology of cereal grain and cereal products. In: Cereal Grain, Mycoloxins, Fungi and Quality in Drying and Slorage, edited by J. Chelkowsky, Elsevier Science Publishers, Ansierdam. pp: 23.52 .

Moss, M.O. (1998). Recent studies of mycoloxins. J. Appl, Microbiol. Symp. Suppl. 84:62S-76S.

Motomura, M. MIrooka, E.Y. (1996). Antifungal sibsiance producing microorgamisms wilh perspective of applicalions in Firsarium moniliforme control. Arq. Biol. Technol. 39(2): 471479.

Nelsom, P.E., Platiner, R.D., Slinckelford, D.C. \& Desjardins, A.E. (1992). Fumonisin B, production by Fllsorinm species oller than Fusurom monilforme in sestion Liseola and by sone related 
species. Appl. Environm. Microbiol. 38: $984-989$.

Nelson, P.E., Desfardins, A.E. Plactner, R.D. (1993). Fumonisins, mycoloxins produced by Fisarmm specics: biology, chemistry and significance. Aut. Rev. Phytopalhol. 31: 233- 252.

Neurece, J.N. (1992). Electrophoretic analysis of cationic extracted from aflatoxin registant susceptible varielies of corn. J. Agric. Food Chen. 40: 1422-1424.

Neurece, J.N, \& Godshall, M.A. (1991). Errecls of base-soluble proteins and melhonol soluble polysaccharides from con on mycolial growli of Aspergilins Rawns. Mycopathologia 113: 103-108.

Nout, M.J.R. (1989). Elfeet of Rhiropus and Neurospora spp. on growh of Aspergilhus founs and Aspergilhs parositicus and

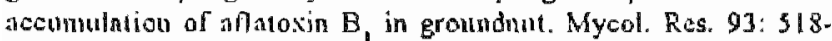
523.

Nour, M.J.R. (1995). Fungal interactions in food fermentations. Can. J. Bol, 73 (suppl. 1); S1291-S1300.

Ono, M. \& Kinura, N. (1991). Antihungal peplides produced by Bacillus subulis for the biulogical conrol of atolocim contanination. Proc. Jpn. Assoc. Nycotanicol. 34: 23.28.

Ono, M., Snkuda, S., Suzulit, A. \& Isugini, A. (1927). Mlasialin A, a novel inhibitor of allatosin production by allatosigenie hangi. J. Antibiotics 50(2): 111-118.

Papn, K. Ex (1979). Geneticy of Aspergillas flavus: Complementation and mapping of aflatoxin mulans. Genelic Res, 34: 1-9.

Pastey, N., l'ushinsky, A., Menngherov, M. \& Chet, H. (1992). Mhibilory ellect of Aspergillis ochracens and Aspergillus flaws, on allatoxin formation. J. Sci. Food Agric. 58: 589.591 .

Pnync, G.A. (1992). Altatoxin in maizo. Crit Rev. Plant Sei. 10: $423-440$.

Payne, G.A. B Brown, M.1. (1998), Genetics and physiology of allatoxin biosynthesis (Review). Arnu. Rev. Phytopathol. 36: 329. J62.

Pier, A.C. (1992). Major biological consequenees of aflatoxicosis in animal producion. J. Auimal Sei. 70: 3964-3967.

Pftet, A. (1998). Natural oceurrence of mycoloxins in foods and, feeds - an updaled review. Rev Med. Vel. 149(5), 479-492.

Pitt, J.1. (1991). Penicilliwm 10xins. ACIAR Proc. 36: 99-103.

PIth, J.I. Lelsiner L (1991). Toxigenie Penicillum species. In: Mycoloxins and Animal Foods, ediled by J.E. Smith \& R.S. Henderson, CRC PTess, Boea Raton, Florida, pp. $91-99$.

Iilt, J.I, Hocking, A.D., Budlinsami, K. \& Miscmul he, L. (1993). The nonmal mycoflora of conmodities from rhailand. Nuts and oildseeds. J. Food Microbiol. 20: 211-226.

Placinta, C.M., D'Mello, J.P. F. \& Macdonald, A.M.C. (1999). A review of worlsvide contamination of cereal grains and animal feed with Fusarinm nycoloxin (Review). Anim. Feed Sci. Technol. $78(1-2): 21-37$

Prelushy, D.B., Rotter, B.A. \& Rotter, R.G. (1994). Toxicology of myeoloxins. In: Mycoloxins in Grain: Compounds ofher than andoxin, edited by J: D. Miller \& H.L. Trenholm, Eagan Press, Si. Paul MN, pp. 359.405 .

Ranjan, K.S. Sahay, S.S. \& Choudlunry, A.K. (1992). Efficacy of spices against anatoxin synthesis. Grobios 19:39.41.

Snmison, R.A., Hoeksira, E.S., Trisvad, J.C. Illienborg, 0 . (1995). Iniroduction to food-borne fungi, Central Butreas voor Selimumelcultures, Baam. Pp. 322.

Santamorina, M.P., Ginenez, F.I., Sabater, C. \& Sanchis, V. (1995). Medidas para la reducción y eliminación de micolosinas. Alimenos y piensos. Rev. Iberoam. Micol 12(4): $52-59$.

Sirdjono, R, Ruhnyu, K \& Sudarnindji, S. (1992). Growli and allatoxin produclion by Asperghllus flaws in mixed cullure with Aspergillis oryzue. ASEAV Food J. 7: 30-33.

Schlllinger, U., Geisem, R. \& Holzaprel, W.J. (1996). Potential of antngonistic microorgtnisus and bncteriocins for the biological preservation of foods. Trends Food Sci. Technol. 7: 158-164. Schroth, M.N. Alnucococle, J.G. (1981). Selected lopies in biologisal coural. Amnu. Rev. Microbiol. 35: 453.476 .

Scall, G.E. \& Zunmo. N. (1988). Sources of resistance in maize to kentiol infection by Aspergilhs fowns in the fheld. Crop Sci. 28: $504=507$.

Scoth, G.E. \& Zummo, N. (1922). Registration of Mp420 gerimplasm line of maize. Crop Sci. 32: 1296.

Scott, J.K. (1995). Classical biological control of plant pathogets. Adv. Plant Pahol. 11: $131 \cdot 146$.

Slanin, T. \& Rall, E.R. (1990). Isolation and chamelerization of aflatoxin-indibiting metabolite from A. niger. Curr. Sci. $591: 326-$ 327.

Shanta, T., Rati, E.R. Dhavani Snakar, T.N. (1990). Behnviour of Aspergullus favus in presence of Asperglllus niger during biosynulesis of afhatoxin $B_{1}$. Anlon. Leeuben. $59: 121-127$.

Sharna, A., Padwal-Desal, S.R. S Nadkarni, G. 1. (1988). Effeet of aldehyde trapping agents on ellylente and allatoxin biogenesis in Aspergillis parasufieus. J. Agric. Food Chen1. 30: $546-$ 548 .

Shotwell, O.L. (1991). Mycotoxins in grain dusts, healuh implications. Ju: Myooloxins and Animal Foods, edited by J.E. Smith \& R.S. Henderson, CRC Press, London. PP. 415-422.

Silva, J.C. Minto, R.E., Barry III, C.C., Holland, K.A. \& Towusend, C.A. (1996). Isolation and characterization of the versicolorin B synthase geve from Aspergllhs parasineus. J. Biol. Chem. 271: $13600-13608$.

Smlth, I. I. \& Moss, M.C. (1985). Mycoloxins, fornation, analysis and siguificance, ediled by Johr Wiley \& Sons, Londres.

Smith, J.E. \& Henderson, R.S. (1991), Mycoloxins and animal Foods CRC Press, Florida.

Srutyh, R.L: (1990). Growing corn in Georgin, Univ. Georgia Coop. Ext. Serv. Bull 547. Alhens.

Suljders, C.H.A. (1994). Breeding for Fusorimm resislance in 
wheat and naize. In: Mycotoxins in grains, edited by J.D. Miller \& I-l.L. Trenholn, Eagan Press, Si Paul. pp. 37-58.

Stolorr, L. (1979). The uree eras of fungal toxin resenrch. J. An. Oil Chem. Soc. 56: 684-688.

Swecney, M.J. \& Dobson, A.D.IV. (1998). Mycoloxin production by Aspergillus, Fusarmum and Penicillium species. Int. J. Food Nicrobiol. 43: $141-158$.

Sweency, M.J. \& Dobson, A.D.W. (1999). Molecular biology of nyycaloxin biosynthesis (Revizw). FEMS Microbiol. Lell. 175(2): 149.163.

Tahvonen, R. Hannukkaln, A. \& Avikainen, H. (1994). Effecl of seed dressing treanment of Streptomyces gr/seovindes on barley and spring wheat in field experiments. Agric. Sci. Finland 4: 419427 .

Thlcl, P.G. (1998). The role of natural coxins in environnental poltution. S. Afr. J. Sci. 94(9): 419.422.

Trail, F., Mnlonn1l, N. \& Linz, J. (1995). Molecular biology of afhntoxin biosynllesis. Microbiology (Reading UK) 141: 755-765.

Trejo-Estrada, S.R., Paszezynshl, A. \& Crawford, D.L. (1998). Antibiolics and enzymes produced by 1)re biocontrol agent Streplomyces violoceousniger YCED-9. J. Ind. Mlicrobiol. Bioleclinol. 21(1-2): $81-90$.

van Lenteren, J.C. (1992). Biological control in protected crops Where do we go?. Pesticide Sci. 36: 321-327.

Wicklow, D.T. (1994). The mycology of stored grain: An ecological perspective. In: Mycology of Stored grain Ecosystems, ediled by D.S. Jayas, N.D.G. White \& W.E. Muir, Dekker, New York, pp. 267-284.

Wicklow, D.T., Horn, B.W, \& Shotivell, O.L. (1987). Aflatoxin formation in preharvest maize ears coinoculated with Aspergillus novus and Asperglllus niger. Mycologia 79: 679-682.

Widstrom, N.W. (1992). Aflaloxin in developing maize: Interactions anong involved biota and perinent econiche factors. In: Handbook of Applied Micology, edired by D. Buantager, E.B. Lillehoj \& D.K. Arora, Vol 5, Marcel Dekker, New York, pp. 23-58.

Widstrom, N.IV. (1996). The aflatoxin problem with con grain Adv. Agron. 56: 219.280.

Widstrom, N.W., McMllian, W.W., Beaver, R.W. \& Wilson, D.M. (1990). Weather associated clanges in anatosin contamination of preharves1 naaize. J. Prod. Agric. 3: 196.199.
Wldstrom, N.WV., Wilson, D.M., Rlchard, J.L. \& Mc.Millian, W.W. (1994). Resistance in maize to preharvest contamination by aflaloxin. Trends Agric. Sci. (Planll Palliol.) 1: 49-54.

Widstrom, N.IV., Ms Mlliam, W.W., Wilson, D.M., Richnrd, J.L., Zunimo, N. \& Benver, R.IV. (1995). Preharvest anatoxin contamination of maize inoculated with Aspergillus flaws and Fusarium montliforme. My'copathalogia 128: 119-123.

Willson, D.M.. IVidstrom, N.W., NcMillinn, W.W. \& Bcaver, R.W. (1989). Anatoxins in corn. [n: Proceedings 44ll Annual Com and Sorglum Resenrclus Conferences, Chicago IL., pp. 1-23.

World Fleallh Organization. (1990). Envirommental heallh criteria for selected mycotoxins: ochratoxins, trichothecenes and ergot, Vammalan Kirjapaino Oy Editorial, Vnmmala.

IVyatt, R.D. (1991). Poultry. In: Mycotoxins in animal foods, edited by J.E. Smilh \& R.S. Henderson, CRC Press, Boca Ralon, pp. 553- 606

Yu, J.J., Chang, P.K, Cary, J.W., IVright, M., Bhatnager, D. Cleveland, T.E., Payne, G.A. \& LInz, J.E. (1995). Comparalive mapping of aflatoxin pathway gene clusters in Aspargil/hs parasilicus and Aspergillus flavus. Appl. Environ. Microbiol. 61: 2365.2371.

Zntka, L.L. \& Buchanan, R.L. (1987). Review of compounds affecting the biosynthesis or bioregulation of aflatoxins. J. Food Prol. 50: 691-708.

Zeringue, H.J. (1991). Effecl of $\mathrm{Cb}$ and $\mathrm{C}_{g}$ alkelsals on aflatoxin production in corn, collonseed, and peanuts. Appl. Environ. Microbiol. 57: 2453-2434.

Zeringue, H.J. \& Bhatnnger, D. (1994). Effects of necin leaf volatiles on submerged cultures of aflatoxigenic Aspergillus parasiticus. Appl. Enviroll. Microbiol. 60: 3543- 3547.

Zuber, M.S. (1977). Inflnence of plant genetics on toxin production in coris. In: Mycoloxins in human and animal heallh, edited by J.V. Rodricks, C.W. Hesselline \& N.A. Melilmann, Pallotoxic Publishers. Park Foresı Souslı IL. pp. 173.179.

Zuber, M.S. \& Lillelioj, E.B. (1979). Stalus of aflatoxin problem in corn. J. Environ. Quality 8: 1-5.

Zummo, N. (1991). Concurtent infestion of individual com kemels wilh while and green isolates of Aspergillus folus. Planc Dis. 75: 910.913 . 